\title{
Conflict, consensus and dissensus in two open letters
}

A Common Word between Us and You and "A Common Word" Christian Response

Conflit, consensus, dissensus dans deux lettres ouvertes : A Common Word

between Us and You et "A Common Word" Christian Response

\section{Mohamed Saki}

\section{(2) OpenEdition}

\section{Journals}

\section{Electronic version}

URL: http://journals.openedition.org/tipa/1936

DOI: 10.4000/tipa.1936

ISSN: 2264-7082

\section{Publisher}

Laboratoire Parole et Langage

\section{Electronic reference}

Mohamed Saki, «Conflict, consensus and dissensus in two open letters », TIPA. Travaux interdisciplinaires sur la parole et le langage [Online], 33 | 2017, Online since 06 September 2017, connection on 26 September 2020. URL : http://journals.openedition.org/tipa/1936 ; DOI : https:// doi.org/10.4000/tipa.1936

This text was automatically generated on 26 September 2020 .

\section{(1) (1)}

La revue TIPA. Travaux interdisciplinaires sur la parole et le langage est mise à disposition selon les termes de la licence Creative Commons Attribution - Pas d'Utilisation Commerciale - Pas de Modification 4.0 International. 


\title{
Conflict, consensus and dissensus in two open letters
}

\author{
A Common Word between Us and You and "A Common Word" \\ Christian Response \\ Conflit, consensus, dissensus dans deux lettres ouvertes: A Common Word \\ between Us and You et "A Common Word" Christian Response
}

Mohamed Saki

\section{Introduction}

1 'Conflict' is a generic term that, broadly, refers either to a physical confrontation or to a verbal expression of disagreement. In the latter case, discussants use various rhetorical and discursive strategies either to reach consensus or to deepen discord. I will analyze in this article how discussants deal with a conflict situation in two open letters issued after Pope Benedict XVI's Regensburg lecture. On September 12, 2006, Pope Benedict XVI gave a lecture at the University of Regensburg on faith and reason in Christianity. This academic lecture sparked an international controversy and heated reactions in many Muslim countries because, in the course of his lecture, Pope Benedict XVI quoted the Byzantine Emperor Manuel II who considered Islam as a violent and unreasonable religion. Many in the Muslim countries mistook the quotation and considered that the pope endorsed the Byzantine emperor's point view of Islam as "evil and inhuman." Some of the reactions to Pope Benedict's allegedly negative representation of Islam were very violent and blatantly hostile to the West and to Christians in general; others, however, were more rational and unemotional. Thus, On October 12 of the same year, Islamica magazine published An Open Letter to His Holiness Pope Benedict XVI, as a response to the pope's lecture, signed by 38 Muslims scholars and leaders (islamicamagazine,com). A year later, on October 13, 2007, this open letter was followed by a second one: A Common Word between Us and You, signed by 138 Muslim scholars and religious leaders from Muslim and non-Muslim countries (Russia, the United States, etc.) The phrase 'a common word' is taken from a verse in the Qur'an, in 
which the prophet of Islam invited the people of the scriptures (Jews and Christians) to unite in the worship of God. This second letter was not addressed to the Pope exclusively, but to all Christian leaders all over the world; it took the form of an invitation to an open and rational dialogue between the two religions. The text triggered many reactions, some hostile and others warm and congenial. A case in point for the latter is the Yale Center for Faith and Culture's "A Common Word", Christian Response.

2 I will explore the communicative rationality the writers A Common Word between Us and You (henceforward ACW) and "A Common Word" Christian Response (henceforward CR), resort to in order to bridge the gap between Muslims and Christians, eradicate conflict and disagreement between them. I will first show that far from being transparent and unproblematic, "conflict" is a highly vexed term that has always triggered deep political and philosophical debates and disagreements. I will then analyze the expressions consensus and agreement from a rhetorical perspective, with the help of notions such as audience, ethos, kairos, identification, presence. Finally, I will show that despite the insistence on consensus and agreement, dissensus and disagreement slightly persist in this epistolary exchange.

\section{Conflict, consensus, dissensus}

3 The word conflict is a hypernym that may refer, according to Roget's Thesaurus, to a struggle, clash, battle, contention, strife, opposition, collision, disagreement, row, quarrel, controversy, etc. It has a highly negative connotation and it subsumes different forms of active opposition between at least two parties. For this reason, conflict is considered as a symptom or manifestation of a failure of some sorts; ideally, it is to be avoided and its positive counterparts, agreement and consensus, should prevail at the end of each human interaction, be it personal or collective (Amossy, 2014).

4 This dismissive attitude towards conflict has predominated in the field of social sciences and political philosophy for decades. For Jürgen Habermas, conflict should only characterize the beginning of a public dialogue and it should be resolved by consensus, which is the telos and the ideal regulator of human interactions. From the perspective of deliberative democracy, of which Jürgen Habermas is one of the most prominent representatives, authentic public dialogue is a process that aims at producing a valid and justified consensus. It is established by a process of mutual agreement upon significant values and symbols and it is built on communicative rationality, which is characterized by:

... the unconstrained, unifying, consensus-bringing force of argumentative speech, in which different participants overcome their merely subjective views and, owing to the mutuality of rationally motivated conviction, assure themselves of both the unity of the objective world and the intersubjectivity of their lifeworld." (Habermas, 1984: 10)

5 Jürgen Habermas's discourse ethics establishes a strong link between consensus, reciprocity, justification and reason giving (1986: 141 ; 1992: 99); the communicative rationality he promotes provides discussants with a procedure for ascertaining the intersubjective validity of a claim and the formation of a common will in public dialogue. In Jürgen Habermas's discourse ethics, the validity of moral and political norms can only be established by an intersubjective and idealized practice of 
argumentation (1992: 22). For, indeed, once engaged in a public dialogue, discussants tacitly commit themselves to justifying their claims and supporting them by rational arguments and claims which have to be intersubjectively valid and mutually accepted. As a consequence, the claims issued by each discussant call for a discursive and pragmatic analysis so as to bring to the fore the logics of argumentation at work and the normative presuppositions that inform the public dialogue.

6 Jürgen Habermas's perspective is premised on the power of persuasion between rational partners engaged in a rational and tempered exchange; each using different rhetorical strategies and each having a drive for consensus. Obviously enough, he is far from naïve and he is aware that this is but an ideal-typical situation for, in reality, human interactions and public dialogues are, more often than not, characterized by a persistent mutual misunderstanding, deep and incommensurable disagreements. In fact, conflict is not always conceived of negatively; it has also been theorized, by many thinkers, such as John Rawls (1996), Christian Kock (2007), Jacques Rancière (1995; 2009), Chantal Mouffe $(1999$; 2016), to mention but a few, as a highly positive philosophical and rhetorical category which sheds light on how certain issues are tackled in a society. The different modalities and expressions of conflict in the public sphere and the ways they are handled are indicative of the solidity of the democracy or of its weakness. Consequently, consensus should not be viewed as the only legitimate and acceptable endpoint of a debate or conflict situation; in some cases, it may even be indicative of the absence of a genuine pluralism. For these thinkers, pluralism and divergences in opinions in stances towards political, social or societal issues are the sine qua non condition for a genuine democracy. Therefore, instead of standing for communicative failure or a dialogue of the deaf (Angenot, 2008), conflict may also be a symbol of a dynamic, pluralistic democracy.

7 In John Rawls's theory of liberal and democratic pluralism (1996), disagreement, as a discursive expression of conflict, is not due to irrationality, prejudice, or self-interest; it may be due to the very nature of a truly open society. The latter is a society where enduring and fathomless disagreements over a wide range of moral, ethical, and other philosophical matters are acceptable. Actually, conflicts and unresolved disagreements do persist even after a long discussion regulated by all the precepts of rationality, moderation and reasonableness. What prevails in such cases is what John Rawls calls "reasonable disagreement" and "overlapping consensus"; these two notions provide us with a way out of the rigid and reductionist binary oppositions between consensus and dissensus, agreement or conflict, etc. To John Rawls, reasonable disagreement on divergent moral, religious and philosophical worldviews is possible and legitimate when there is a shared commitment to a common sense of fairness and mutual confidence (Rawls, 1996: 137). Indeed, it is only possible and legitimate when disputants comply with the ideal of public reason which involves the existence of a reasonable pluralism concerning religious and personal ethical ideals (Rawls, 1996: 50).

8 To Jacques Rancière, dissensus is not a quarrel over personal interests or opinions; it is a political process and an instance of litigation (Rancière, 1995 ; 2009). It creates a fissure in the sensible order by confronting an established framework of perception, thought, and action with what may be held as an 'inadmissible" framework (2009: 187). Therefore, dissensus is the essence of politics because it makes of democracy the "count of the unaccounted" and it enables the political subject to establish a new scene of enunciation from which silenced, marginalized, dissenting, or opposing voices may 
speak out. In Jacques Rancière's theory, dissensus is a powerful means for securing a pluralistic public sphere and it is always to be grounded on the deliberative virtues of "reasonableness".

9 Chantal Mouffe (1999), too, insists on the importance of political conflict, agonism, and disagreement. She dissociates agonism from antagonism by calling for a rehabilitation of the agôn logôn, or the contest of speeches, which stresses the crucial role of persuasion, argumentation, as well as a respect for the opponent who is not seen as the enemy but as an adversary. Mouffe criticizes, from a post-political perspective, the illusion according to which the exchange of reasoned arguments will lead to an inclusive, rational, universal consensus (2016: 55). Besides, Chantal Mouffe's agonistic pluralism seeks to bring to the fore the contradictions of those political or philosophical theories that invoke rationality as a normative regulator of public dialogue and which are, according to her, usually prone to marginalize or exclude dissenting and adversarial voices. To Chantal Mouffe, it is impossible to have consensus without exclusion since consensus explicitly or implicitly rules out the possibility of rational and legitimate dissent (1999: 755). Since, in her theory, consensus always goes hand in hand with a form of exclusion, be it implicit or stark, it is in the last analysis but one the many disguises of hegemony.

10 Andrew Knops (2012) views the opposition between consensus and agonistic dissensus as artificial to some extent; to him, agonism is not necessarily an obstacle to or antagonistic with deliberation; he maintains that deliberation and agonism are complementary. Therefore, instead of opposing deliberation and the rational search for consensus to Chantal Mouffe's agnostic (1999: 2016) pluralism, he contends that each perspective stresses different facets of the same project (2007: 125), hence his emphasis on the possibility of integrating "agonism as a theory of the moment of difference within a broader deliberative dialectic" (2012: 153).

When dealing with conflict, consensus and dissensus, we should, Christian Kock (2007) stresses, make a distinction between two domains of arguments: episteme and praxis. Episteme arguments are about what a discussant considers as true, intangible and undisputable, while praxis is about the right norms of action and about what to do in a particular situation (2007: 182). Another distinction follows from the first one, a distinction between theoretical issues and practical issues. Christian Kock (2007) upholds that at the end of a reasonable and regulated dispute, discussants can and may reach a consensus and a common understanding of a theoretical question, while on practical issues, which are essentially about choice, "people may find themselves in legitimate and enduring dissensus" because "the possibility of choice entails the legitimacy of enduring dissensus" (2007: 183). He adds that, in practical issues, there is a strong element of subjectivity that cannot be eradicated; this is why conflict can rise between equally relevant reasons and why "even reason people arguing reasonably cannot be expected to reach consensus in the domain of practical reasoning" (2000: 190).

12 As we have seen, the aforementioned thinkers and scholars, except of course Jürgen Habermas, do not consider consensus as the ideal endpoint to all debates, on the one hand, and, on the other, they stress the importance of conflict and dissensus in public dialogue. Two premises are of particular importance to the analysis of discursive and rhetorical construction of conflict and consensus in this article. First, it's my contention that any analysis of conflict and disagreement should take into account the 
distinction between the types of arguments, introduced by Christian Koch. Second, my analysis is premised on the fact that each consensus presupposes the exclusion of a "third". I will show why these two premises account, to a great extent, for the rhetorical choices and strategies resorted to by the signatories of both open letters to handle a thorny issue such as the inter-faith dialogue in a moment of heightened tension.

\section{The two open letters and their audiences}

The two texts analysed belong to the epistolary discourse; in fact, open letters constitute within the epistolary discourse a subgenre with specific discursive features and pragmatic aims. An open letter may be written by a lay citizen or a group of lay citizens as it may be signed by a public figure; each speaks in their own names but also in the name of wider portions of citizens or even in the name of a whole community. Generally, an open letter targets two different audiences; first, it addresses a particular (public) figure who is endowed with an important symbolic capital and who stands metonymically for a wider community, institution, etc.; second, it addresses the general opinion, the whole nation, international community, etc. Besides, it may address a concrete person (Mrs or Mr. So-and-So) or an abstract entity (human conscience, France, America, etc.). Finally, an open letter aims to form attitudes and induce actions in its audiences since one of its intended perlocutionary effects is to make the addressees aware of a particular situation and to propose the adequate responses to it. An open letter typically seeks to raise collective conscience and have the targeted audiences act collectively to redress a wrong, to actively take part in finding a solution to a public issue (Saki 2013a ; 2013b ; 2016).

14 As we can see, the questions of addressivity and audiences are crucial when dealing with the open letters since the message they convey is shaped to a large extent by the audiences they are addressed to. I will analyze the audiences constructed by the two open letters with the help of Chaïm Perelman's reconceptualization of "audience" which he elevated to almost unprecedented height in rhetorical studies (2008). According to Perelman, the aims of all argumentation is to win over other people and to create or increase adherence of minds to the theses presented for their assent (2008: 22-25). To Perelman, argumentation is always audience-oriented and its soundness depends on whether it appeals to the audience or not. To him, "[i]t is indeed the audience which has the major role in determining the quality of argument and the behaviour of orators" (2008: 24); consequently, the techniques used by the arguer must also correspond to the audience's "frame of reference." Finally, Perelman distinguishes between two categories of audience: "particular audiences" and a "universal audience" composed of reasonable and rational people and it is the regulative ideal of maximal intersubjective agreement that appeals values and principles that enjoy unanimous approval (2008: 40-44).

As far as audiences are concerned, the two open letters analysed in this article also target a particular audience and a universal one. The first audience is composed of the direct addressees of each text; i.e. Christian leaders and Muslim scholars, respectively. As we now know, the primary addresses of an open letter always have a metonymic status; therefore, the two open letters under scrutiny in this article go beyond the 
primary interlocutors and address the religious communities they stand for, that is all Christians and all Muslims:

1. Let us vie with each other only in righteousness and good works. Let us respect each other, be fair, just and kind to another and live in sincere peace, harmony and mutual goodwill. (ACW)

2. "Let this common ground"-the dual common ground of love of God and of neighbour-"be the basis of all future interfaith dialogue between us," your courageous letter urges. Indeed, in the generosity with which the letter is written you embody what you call for. (CR)

The intersubjective relationship established between the writers of open letters and their particular audiences is characterized by congeniality and empathy. Indeed, in neither text are there any face-threatening acts, ad hominem attacks or aggressive interpellations; the signatories pledge benevolence and good will when addressing each other.

Besides, these particular audiences, the two letters address a universal audience as well. In fact, the intersubjective relationship established in this epistolary exchange and the choices made to deal with the Christian-Muslim dialogue in a time of growing tension can be fully grasped only by taking into account the address to this universal audience before which both letters expose the ethical soundness of their arguments:

3. As Muslims, we say to Christians that we are not against them and that Islam is not against them-so long as they do not wage war against Muslims on account of their religion, oppress them and drive them out of their homes. (ACW)

4. Since Muslims seek to love their Christian neighbors, they are not against them, the document encouragingly states. Instead, Muslims are with them. As Christians we resonate deeply with this sentiment. (CR)

In certain passages of the two texts, the primary addressees are "delocuted" and referred to by "Christians" and "Muslims", and there is a total absence of pronouns such as "you" or "your." Such an absence of "you" and "your" underscores the fact that the inter-faith dialogue is performed in front of a universal audience; an audience to which each group stresses its moral rectitude, its ethical conduct and its commitment to using reason, facts and truths instead of partial and partisan considerations. As we can see, appealing to the universal audience is highly reflexive since the letter signatories show how reasonable, open, and tolerant their religion and the stance they are adopting are, as we will see below.

19 The appeals both to particular audiences and the universal one shed light on the type of intersubjective relationship established in this epistolary exchange; the latter is characterized by a deep commitment to mutual respect and reason. These intersubjective harmony and proximity frame the way the conflict situation is dealt with in these two letters because, as we will see, the writers of the letters constantly reiterate the convergence of their stances and values in order to foster consensus.

\section{Kairos and consensus}

The epistolary exchange takes place against an immediate background-Pope Benedict XVI's Regensburg lecture and the tempestuous controversies it unleashed-and a broader one-the aftermath of the terrorist attacks of September 2001 and the clash of civilisation trope they reinvigorated. This extra-discursive context shapes to a great extent their contents, the intersubjective relationship they construe with their 
audiences, the ethos that stands out from each of them as well as the ways in which conflict, consensus, and dissensus are dealt with.

The writers of both open letters agree on identifying a similar kairos, that is the right moment and the right to speak; they have the same sense of appropriateness and timeliness, which, in turn, plays a crucial role in the rhetorical choices made in the two texts. To show their awareness of the particular kairos, the signatories repeatedly stress that their texts are issued at the right time and that they represent the right measure to calm down the ever expanding wrangling about Pope Benedict XVI's lecture:

$5 . .$. its signatories recognize te critical character of the present moment in relations between Muslims and Christians. (CR)

6. Our common future is at stake. The very survival of the world is perhaps at stake (ACW)

7. The future of the world depends on our ability as Christians and Muslims to live together in peace. (CR)

The writers of the open letters concur on the fact that their dialogue is brought about by particular historical circumstances and that it is important, in such critical moments, to engage in dispassionate exchange between reasonable people. The language used to describe the kairos of this epistolary exchange is highly evocative and extremely infused with strong affect (terrible weaponry, peaceful relations, survival of the world, critical character, etc.). It describes a present situation laden with threats and tension and vibrant with future orientations, which range from conflict and tension to peace and collaboration.

These lexical choices reveal that both parties have a converging perception of the dramatic situation and of the necessity to act and to prompt in each other inclinations towards open cooperation in, what the signatories depict as, dire times. By choosing the right kairos to engage with each other in mutual respect, the signatories of both letters indicate that they have the appropriate understanding of an uncertain and potentially explosive present situation. They seize the right and good kairos to intervene and craft the opportune and adequate response. A response that leaves enough space for each party to expose its values and stress the similarities in the ways of appraising the present situation and the solution they will propose. By seizing the good kairos, the signatories also show how aware they are of the necessity to be tactful and of the importance of engaging in an open dialogue between rational and good willing believers.

In sum, kairos and the sense of urgency stress the signatories' awareness of the necessity to act now in order to avoid the worsening of the situation or the deepening of the divide that might separate the two religions. It is this awareness of the particularity of the kairos of their exchange that makes the exchange a window of opportunity that may enable moderate and rational people from both religions to address each other and set an example for others to follow.

\section{Identification and presencing}

Another important rhetorical strategy deployed by the two open letters to foster consensus between them is what Kenneth Burke terms identification (1950/69a: 203). In Burke's rhetoric, identification implies that a common ground is being sought and cooperation is being induced or increased between discussants. Spotting the identification processes in the two letters will help us bring to the fore their writers' 
endeavour to construct a consensual, harmonious inter-faith discursive community. These identification processes are further reinforced by the rhetorical process of presencing; Perelman maintains that "the very fact of selecting certain elements and presenting them to the audience, their importance and pertinency to the discussion are implied. Indeed, such a choice endows these elements with a presence, which is an essential factor in argumentation and one that is far much neglected in rationalistic conceptions of reasoning" (Perelman \& Obrechts-Tyteca, 1969: 116). Therefore, choosing certain elements and making them salient are of paramount importance in argumentation and of great pertinence to how discussants construe their frame of references.

The signatories of the two texts ideally identify with each by using an "assumed we" i.e. a community of monotheist believers who transcend religious affiliations and delineations and who are fused into a Christian-Muslim "we":

8. ... as Muslims, and in obedience to the Holy Qur'an, we ask Christians to come together to come with us on the common essentials of two our religions the common essentials of two our religions(ACW)

9. ... for our common ground is that on which hangs all the Law and the Prophets (Matthew 22:40). mon ground(ACW)

10. "A Common Word Between Us and You" identifies some core common ground between Christianity and Islam which lies at the heart of our respective faiths (CR)

11. We find deep affinities with our own Christian faith when "A Common Word Between Us and You" insists that love is the pinnacle of our duties toward our neighbors (CR)

Identification by an "assumed we" has the advantage of explicitly suggesting uniformity and common purpose. The frequent uses of "we" and "us" and the insistence on what they have in common consolidate a strong unity between members of both religions and stress the commonality of their spiritual values and messages. "We, us, our" bridge the initial gap that existed between "You" and "Us" and coalesce the two parties in what is presented as an ideal harmonious and undifferentiated community of believers. The signatories of the two open letters carve out the "assumed we" by giving salience to foundational values that embody the community of their aims: "the common essentials of two our religions ;" "our common ground "" "core common ground between Christianity and Islam;" "We find deep affinities with our own Christian faith."

By emphasizing this "assumed we," the two parties make the most of one of the basic characteristics of any epistolary exchange: the centrality of the "We-You" relationship. The latter implies a reciprocity whereby the original "you" is not silenced and subordinated out of existence, but is invited to become the "We." Indeed, the predominance of the "assumed we" in the texts analyzed in this article bolsters the intersubjective bond between the two parties and, more importantly, highlights their consubstantiality and their deep affinities. Christians and Muslims are, thus, consubstantial to each other since they share the same substance and they belong to the same spiritual community. Their views and values are not irrevocably antagonistic, but deeply consonant with each other, albeit their being from different faith communities. The "assumed we" celebrated by both texts is the bedrock of their dialogue and, therefore, they can but unite around their common values and promote their mutual inclinations towards consensus, instead of fuelling conflict. 


\section{Conflict and the consensual ethos}

Throughout their texts, the signatories repeatedly indicate that they are not engaged in a dispute or litigation between two hostile parties, with irrevocably irreconcilable positions, telling unvarnished truths to each other. Neither open letter passes negative value judgments on the other party's stances and beliefs because their ultimate and overriding aim is to eradicate conflict and dissensus. In fact, a consensual, moderate ethos (Amossy, 2010) stems from these two letters since the writers of both letters yearn to show that they know and observe the principles of valid reasoning and that are sensible, upright and, most of all, well-disposed to each other. This consensual ethos is also the outcome of the signatories' efforts to transform an initial conflictual and polemical issue-Pope Benedict XVI's Regensburg lecture and the ensuing controversies -into an event of consensual symbolism. It is equally indicative of their common, adequate grasp of the situation and of the necessity to adopt an unprejudiced and benevolent attitude to each other in order to work out the right solutions. Openness to each other and unbiased stances are reinforced by the frequent quotations of the Muslim sacred texts by the Christian response and by references to the Bible by the Muslim signatories:

12. The Prophet Muhammad did similarly when he was violently rejected and stoned by the people of Ta'if. He is known to have said, "The most virtuous behavior is to engage those who sever relations, to give to those who withhold from you, and to forgive those who wrong you. (CR)

13. The commandant to love God fully is the First and Greatest Commandment in the Bible. Indeed, it is to be found in a number of other places throughout out the Bible including: Deuteronomy 4:29, 10:12... Mark 12:31-33 and Luke 10:27-28 (ACW) 14. The basis for this peace and understanding already exists. It is part of the very foundational principles of both faiths: love of the One God, and love of the neighbor. These principles are found over and over again in the sacred texts of Islam and Christianity. (ACW)

This particular consensual ethos is one of the rhetorical devices used in the two open letters to highlight how each party strives to reach an agreement around a set of values and a suitable line action in a time of turmoil and increasing inter-faith tension. The consensual ethos gives more prominence to the spirit of cooperativeness between partners who stand on an equal footing:

15. Let this common ground be the basis of all future interfaith dialogue between us, for our common ground is that on which hangs all the Law and the Prophets (Matthew 22:40). (ACW)

16. "Let this common ground"-the dual common ground of love of God and of neighbor-"be the basis of all future interfaith dialogue between us," your courageous letter urges. Indeed, in the generosity with which the letter is written you embody what you call for. We most heartily agree. (CR)

31 The consensual ethos that emerges from this epistolary exchange contributes, therefore, towards downplaying conflict and to foregrounding the positives values, such as temperance and magnanimity, that characterize their dialogue. This very consensual ethos constructs a mental image of nearness between the discussants and strips the two letters from what may cause alarm or opposition. Finally, the consensual ethos that predominates in the two texts reinforces the major claim of the two parties: the necessity and possibility to have an open and well-intentioned exchange so as to

TIPA. Travaux interdisciplinaires sur la parole et le langage, 33 | 2017 
stand up to what the situation requires. Besides, it makes the telos of their public dialogue more salient: to reach consensus, by minimalizing divergences, in order to wither away all sources of potential conflict.

\section{Dissensus beyond consensus}

Consensus building is possible in these two open letters because, as we have seen, what is at issue belongs to the episteme type of arguments. The discussants downplay and erase conflict and controversy between Muslims and Christians; they bear out their agreement by using the same rhetorical code of reasoning and the same rationality; as a result, the quantum of divergence and the risks of potential conflict seem infinitesimal. Indeed, they agree on what is debatable, arguable in a cordial exchange regulated by a universal and transcendental reason by whose rules they abide. Through consensus, they aim to expunge the differences of perspectives in their dialogue, or at least to tone them down, by repeatedly underlining the consubstantiality of their values and the almost absence of disparities between the believers of the two faiths.

However, this epistolary exchange raises at least two questions: to what extent is this epistolary dialogue a genuine one? Correlatively, to what extent is the consensus reached an unfeigned one? As a matter of fact, even if the open letters writers avoid adopting agonistic stances and stamp out any spirit of adversariality, the two letters have, at times, a judicial overtone. As we have seen above, the apparently inclusive claim of consensus building always presupposes a mechanism of exclusion. Even if the discussants adopt an ethically neutral stance towards each other, their consensus is fostered at the expense of an excluded "third" whose competing claims are nebulously referred to and dismissed as irrational, dangerous:

17. That so much common ground exists-common ground in some of the fundamentals of faith-gives hope that undeniable differences and even the very real external pressures that bear down upon us cannot overshadow the common ground upon which we stand together $(\mathrm{CR})$

18. To those who nevertheless relish conflict and destruction for their own sake or reckon that ultimately they stand to gain through them, we say that our eternal souls are also at stake if we fail to sincerely make every effort to make peace and come together in harmony (ACW)

The "third" in these open letters is referred to in vague and abstract terms: "pressures that bear down upon us," "those who relish conflict and destruction", the writers refuse to engage with it agonistically, to word its claims and arguments and they relegate it to an irrational and dangerous sphere. By so doing, they rule out even the possibility of a rational and legitimate dissensus. Obviously enough, the ominous and unnamed figure of the "third" plays a crucial role in further buttressing the bond between the discussants and, obliquely, enables the signatories to allocate themselves the positive roles of sensible and rational partners.

The reference to this vague and threatening "third" reinforces the process of identification thanks to the rhetorical process of dissociation or antithesis. The unnamed, excluded third enables them to come out with an "us-versus-them" polarization and its cognitive structure of thinking in binaries. The dividing line in this symbolic topography doesn't oppose Muslims to Christians, but both Muslims and Christians to a common enemy. This enemy shores up the probity of the discussants' agreement and its supposedly unbiased and reasonable foundation. 

between Christians and Muslims, but only allusively:

19. Muslims and Christians have not always shaken hands in friendship; their relations have sometimes been tense, even characterized by outright hostility. (CR)

20. Given the deep fissures in the relations between Christians and Muslims today, the task before us is daunting. And the stakes are great. (CR)

21. Whilst Islam and Christianity are obviously different religions-and whilst there is no minimizing some of their formal differences-it is clear that Two Greatest Commandments are an area of common ground and a link between the Qur'an, the Torah and the New Testament. (ACW)

The signatories, in their quest of consensus and the eradication of dissensus, invoke divergences between Christians and Muslims, ("deep fissures") and euphemize them at the same time. In 21 , the concessive construction starts by admitting the existence of differences between the two religions but relegates these differences to the status of "formal differences" which do not concern their most fundamental creeds: love of God and love of the neighbor.

The consensus enacted in this epistolary exchange artificially obliterates the inherently pluralistic dialogicality of such a spiky issue as the inter-faith dialogue. As a matter of fact, the open letters' writers refuse to admit the existence of discordant and dissenting voices and they refuse to accept the agonistic and dissensual dimensions of these voices. In these texts, Muslims and Christians are presented as two monolithic entities with no dividing lines between them or inside each religion. In doing so, they seek to keep at bay the potential disruptive force of the dissenting claims for no real space is left for those who oppose the signatories' stances and the rationale that underlies them.

By debarring dissensus, both parties have chosen to strategically divest their dialogue of any possible contradiction and opposition. They preclude voices that contest their consensus and they both unwittingly and authoritatively create an infallible ethos because it is them who, in the last analysis, decide who and what values are excluded and included. Consequently, what is presented as the virtues of a reasonable debate openness to question, free exchange and mutuality-is also employed as an instrument for silencing and nearly stifling divergent and contestatory points of view. Yet, despite their efforts to obviate genuine dissensus and to minimize their disagreement, some divisive and thorny theological issues still remain as a potentially serious source of contention that may threaten and undermine the harmonious interfaith dialogue the discussants endeavor to stage in their letters. A case in point here is the triune nature of Christ:

22. Muslims recognize Jesus Christ as the Messiah, not in the same way Christians do (but Christians themselves anyway have never all agreed with each other on Jesus Christ's (عليه سلام [peace be upon him]) nature), but in the following way: .... the Messiah Jesus son of Mary is a Messenger of God and His Word which he cast unto Mary and a Spirit from Him.... (Al-Nisa', 4:171). We therefore invite Christians to consider Muslims not against and thus with them, in accordance with Jesus Christ's (عليه سلام [peace be upon him]) words here. (ACW)

41 Even if both parties aim to wipe out the theological divergences that exist between Christianity and Islam, Muslim religious leaders and scholars deny the triune nature of the Christ. They, thus, perpetuate an age-old debate and lodge a theological critique that can possibly jeopardize the consensus between the two parties. This potentially disruptive claim is downplayed but the concessive statement ("but Christians

TIPA. Travaux interdisciplinaires sur la parole et le langage, 33 | 2017 
themselves anyway have never all agreed with each other on Jesus Christ's"). The concessive subordinate clause redraws the dividing line as regards the triune nature of Christ; it signals that the theological divergence doesn't mean Christians are invited to align themselves on a Muslim point of view of Christ.

\section{Conclusion}

My analysis has shown that the compelling aspiration of this exchange is to stage an open and tuneful exchange as the signatories of both letters circumscribe the perimeter of what can be said and what should be ironed out or left aside altogether. Both open letters emphasize their shared preference for dialogue and consensus instead of fueling confrontation and conflict. They give salience and celebrate what the two religions have in common in order to minimize or eradicate the conflict that may exist between Muslims and Christians.

They seek to alleviate conflict by founding their dialogue on something wider and greater than their own primary communities of belonging, something infinite and profound, however tenuous and fragile it may seem in times of inflamed passions and reactions. They don't seek to gainsay each other, but they constantly acquiesce to what the other party says.

Divergence and dissensus are denied, even if they are implicit in the two texts because this epistolary exchange insists on the possibility for Christians and Muslims to overcome separateness, hostility, and conflict. To reach consensus and reject conflict, the signatories establish a harmonious intersubjective relationship and adopt a noncoercive mode of communication where agency is evenly distributed and empathy is possible (Sell, 2007: 3-4). Indeed, the discussants cultivate a spirit of cooperativeness and stress their agreement on acceptable suitable lines of action in a moment of increasing tension. They rely heavily on the rhetorical mechanism of identification so as to induce cooperation and extol the similarity of their ways of reasoning about the world and about the course of things.

These two open letters illustrate the habermassian conception of intersubjective communication and democratic deliberation; the dialogue they stage is arbitrated by a transcendental and universal reason both parties seem to abide by, reason which also enables them to coordinate future actions. Despite the dire situations in which the letters were issued, the writers indicate that the consensus they have reached is not limited in time and contingent; it is presented as a lasting and reasoned one because it is deeply anchored in their own spiritual traditions.

But as we have seen, the consensus reached and much stressed in the two open letters is obtained by turning a deaf ear to dissenting voices and by minimizing differences and divergences. The signatories seek, throughout their letters, to exclude, downplay or euphemize any divergence and disagreement. By doing so, they contract the dialogic space of a genuine exchange and transform their dialogue into an almost two-voiced monologue, draining, thus, their epistolary exchange from a genuinely pluralistic and dialogic dimension. Indeed, this dialogue may have gained more genuineness had the signatories acknowledged the existence of real and enduring dissensus over a number of contentious historical or theological issues. This would have shown that a consensus is even stronger when a certain degree of dissensus persists. 


\section{BIBLIOGRAPHY}

Amossy, R. (2010), La présentation de soi. Ethos et identité verbale, Paris: Presses Universitaires de France.

Amossy, R. (2014) Apologie de la polémique, Paris: Presses Universitaires de France.

Angenot, M. (2008) Dialogues de sourds. Traité de rhétorique antilogique, Paris: Mille et une nuits.

Burke, K. (1969a) A Rhetoric of Motives (1st ed. in 1950), Berkeley, CA: University of California Press

Burke, K. (1969b) A Grammar of Motives (1st ed. in 1945), Berkeley, CA: University of California Press

Habermas, J. (1984) The Theory of Communicative Action, 2, Boston, MA: Beacon Press.

Habermas, J. (1986) Moral et communication, Paris: Éditions du Cerf.

Habermas, J. (1992) De l'éthique de la discussion, Paris: Flammarion.

Knops, A. (2012) Integrating Agonism with Deliberation-Realising the Benefits [en ligne], Disponible sur: https://doi.org/10.2298/FID1204151K (consulté le 26 juin 2017).

Kock, C. (2007) Norms of Legitimate Dissensus, Informal Logic, 27, 2, p. 179-196.

Mouffe, C. (1999) Deliberative Democracy or Agonistic Pluralism?, Social Research, 6, 3, p. 745-758.

Mouffe, C. (2016) L'illusion du consensus, Paris: Albin Michel.

Perelman, C. \& L. Obrechts-Tyteca (1969) The New Rhetoric, Notre Dame, IN: University of Notre Dame Press.

Rancière, J. (1995) La Mésentente. Politique et philosophie, Paris: Galilée.

Rancière, J. (2009) Et tant pis pour les gens fatigués. Entretiens, Paris: Éditions Amsterdam.

Rawls, J. (1996) Political Liberalism, New York, NY: Columbia University Press.

Saki, M. (2013a) Construction des auditoires et scénographie consensuelle dans 'What we are fighting for', a letter from America in Banks, D. (ed.) Le texte épistolaire du XVII' siècle à nos jours. Aspects linguistiques, Paris: l'Harmattan.

Saki, M. (2013b) Rôles et formes de l'adresse dans la lettre ouverte [en ligne], Le Tour critique, 1. Disponible sur : http://letourcritique.u-paris10.fr/index.php/letourcritique/article/view/12 (consulté le 26 juin 2017).

Saki, M. (2016) Coexistence dans le dissensus ou dialogue de sourds? Analyse des expressions du désaccord dans 'Open letter to 38 Muslim leaders' in Rolland-Lozachmeu, G. (ed.) Les mots en guerre. Les discours polémiques : aspects sémantiques, stylistiques, énonciatifs et argumentatifs, Rennes: Presses Universitaires de Rennes.

Sell, R. (2007) Introduction, NJES, 6, 2, p. 3-11.

\section{Websites}

http://faith.yale.edu/common-word/common-word-christian-response http://www.islamicamagazine.com 


\section{ABSTRACTS}

I will analyze in this article how discussants in two open letters, issued after Pope Benedict XVIth's Regensburg lecture in 2006, seek to reach consensus and overcome disagreement in a particular conflict situation. I first show that "conflict" is a tricky and slippery word and that far from being always negatively connoted, it is, for some thinkers, indicative of the solidity and the genuine pluralistic nature of a society. I carry out a rhetorical analysis against this theoretical background, drawing mainly notions, such as kairos, identification, audience, ethos and presencing, from Kenneth Burke's (1950/69a) and Chaïm Perelman's (Perelman \& ObrechtsTyteca 1958/69) rhetorical theories. I explore how the writers of the two open letters endeavour to bridge up the gap between Muslims and Christians in a time of heightened tension and how they insist, through the rhetorical process of identification, on the consubstantiality of their religions and their stances towards the inter-faith dialogue. The two parties engage in an open dialogue the hallmark of which is a common eagerness to reach consensus and obliterate dissensus and they repeatedly make plain that their dialogue is conducted under the auspices of a transcendental and ethically motivated rationality. Yet, I show that this apparently rational and dispassionate consensus is only reached by excluding a "third" and by refusing to tackle or by minimizing the important dissensual issues.

Le mot «conflit » est générique et il est généralement connoté négativement. Ces deux traits constitutifs ont tendance à surdéterminer notre appréhension de ce qu'il peut recouvrir et y voir le résultat d'un dysfonctionnement ou une source potentielle de tensions. Le but de cet article est d'appréhender la question du conflit à travers l'analyse de deux lettres ouvertes écrites à un moment de tension extrême; nous nous intéresserons plus particulièrement à comment les scripteurs de ces deux textes tentent de dépasser une situation conflictuelle en recourant à des modalités argumentatives qui privilégient le débat dépassionné et les arguments rationnels.

Le 12 septembre 2006, le pape Benoit XVI donna une conférence à l'université de Ratisbonne, en Bavière, dont le thème est le rapport de la raison et de la foi. Dans son allocution, Benoit XVI cita, sans se l'approprier, une phrase d'un message de l'empereur byzantin Manuel II, qui voit dans l'islam une religion cruelle et violente. La conférence suscita des réactions diverses et elle fut à l'origine d'une polémique qui a pris, très vite, des proportions considérables ; certaines ont été violentes alors que d'autres ont été plus dépassionnées. Parmi ces dernières, il y a A Common Word between Us and You, signée par 138 intellectuels et dignitaires religieux musulmans et publiée par le magazine en ligne Islamica Magazine, en octobre 2007. La lettre ne s'adressait pas à Benoit XVI, mais à tous les chrétiens. Cette lettre a suscité, à son tour de nombreuses réactions dont la lettre ouverte intitulée "A Common Word" Christian Response.

Afin d'analyser la façon dont la question du conflit a été traitée dans les deux lettres ouvertes, il nous a semblé important de voir comment la notion même de conflit est théorisée et problématisée par des philosophes. Si, pour Jürgen Habermas $(1984 ; 1986$; 1992), le telos de toute argumentation est le consensus et si le conflit n'est concevable que comme une première phase dans un dialogue public, d'autres philosophes soulignent la fécondité de la notion de conflit et insistent sur l'importance de ne pas le réduire à un échec de la communication. Ainsi, John Rawls (1996) signale qu'il existe des situations où non seulement aucun accord n'est possible mais où le désaccord même est «raisonnable ». Pour Jacques Rancière $(1995$; 2009), le conflit et le désaccord sont l'essence même du politique car ils permettent d'entendre la voix des «incomptés». Chantal Mouffe $(1999$; 2016) met l'accent sur la nécessité d'un pluralisme agonistique, seul à même de faire barrage à toutes les accaparations hégémoniques par les classes dominantes. Pour Andrew Knops (2012), il n'existe pas d'opposition absolue entre agonisme et consensus alors que Christian Kock (2007) nous rappelle que la résolution d'un conflit par le consensus ou la persistance du dissensus dépendent de la nature de la question traitée: 
appartient-elle au domaine de l'épistémè ou au domaine de la praxis?

Ce détour théorique nous permet de montrer que la question du conflit doit prendre en ligne de compte des paramètres à la fois historiques et théoriques pour saisir comment des interlocuteurs s'engagent dans un débat dans une situation conflictuelle. Ainsi, notre analyse de la manière dont les scripteurs des deux lettres ouvertes interagissent dans une situation conflictuelle se fonde sur deux prémisses: d'abord, il nous faut nécessairement faire la distinction entre les types d'arguments utilisés ; sont-ils d'ordre épistémiques ou pratiques? Deuxièmement, il nous faut nous rappeler que tout consensus subsume un tiers exclu. Notre analyse s'appuie sur des notions telles que kairos, identification, auditoire, ethos, (ré)élaborées par Kenneth Burke $(1945,1950)$ et Chaïm Perelman (1958/69).

Nous montrons ainsi que les scripteurs des deux lettres ouvertes s'emploient à effacer toute forme de conflit ou de dissensus en insistant sur la consubstantialité de leurs valeurs respectives ainsi que de leurs visions du monde. L'échange épistolaire est, de ce point de vue, une célébration d'une communauté de croyants, qui regroupe musulmans et chrétiens à la fois. L'analyse montre aussi que pour contourner les questions épineuses et pour surmonter le conflit, les scripteurs font appel à un auditoire universel et fondent leurs arguments sur une raison transcendantale et des impératifs catégoriques et éthiques. Toutefois, l'analyse montre également que le consensus célébré par les deux lettres ouvertes est obtenu par l'exclusion d'un tiers dont on n'entend pas la voix et dont la figure demeure à la fois brumeuse et menaçante. Le consensus est également obtenu grâce à la stratégie d'évitement mis en place par les scripteurs qui s'emploient, dans leur lettre, à minimiser ou à neutraliser des divergences fondamentales entre leurs religions. En somme, mon analyse montre que si le dialogue entre deux religions en situation de tension mis en discours dans les deux peut aboutir à un accord grâce au recours à l'éthique de discussion habermassienne, cette même éthique escamote le débat en laissant peu, ou pas, de place à l'expression d'un dissensus raisonnable.

\section{INDEX}

Keywords: open letter, conflict, consensus, dissensus, argumentation, rhetoric

Mots-clés: lettre ouverte, conflit, consensus, dissensus, argumentation, rhétorique

\section{AUTHOR \\ MOHAMED SAKI}

Université de Bretagne Occidentale, Brest

Mohamed.Saki@univ-brest.fr 